\title{
How former business owners fare in the labor market? Job assignment and earnings
}

\author{
Rui Baptista a,1, Francisco Lima ${ }^{\text {b }}$, Miguel Torres Preto a , \\ ${ }^{a}$ Instituto Superior Técnico, Technical University of Lisbon and IN+, Center for Innovation, Technology \\ and Policy Research, Av. Rovisco Pais, 1049-001 Lisbon, Portugal \\ ${ }^{\mathrm{b}}$ Instituto Superior Técnico, Technical University of Lisbon and CEG-IST, Av. Rovisco Pais, 1049-001 \\ Lisbon, Portugal
}

\begin{abstract}
This study uses detailed longitudinal matched employer-employee data to examine the impact of entrepreneurial experience on job assignments, careers, and wages. The results suggest that there are significant differences in career mobility between former business owners and workers who were always wage employees. Former business owners enter firms at higher job levels and progress faster up the hierarchy than wage employees without entrepreneurial experience. The majority of the former business owners find jobs in small firms. The return to business ownership experience is lower than the return to wage employee experience, thus suggesting that the labor market imposes a penalty for business ownership experience.
\end{abstract}

JEL classification: J31; L26; M51

Keywords: Entrepreneurship, Business Owner Experience; Internal Labor Markets; Task-specific Human Capital; Matched Employer-employee Data.

\section{Acknowledgments}

We thank Mirjam van Praag, George Baker, and participants in the ACE-MPI Workshop on the Costs and Benefits of Entrepreneurship and in the CMU-Portugal Workshop on Frontiers in Entrepreneurship Research: The Interplay of the Entrepreneur and the Firm over their Life Cycles. We are indebted to the Portuguese Ministry of Labor and Social Solidarity for allowing us access to the data used in this paper. Support for this research was provided by the Fundação para a Ciência e a Tecnologia (FCT) through the Carnegie Mellon-Portugal Program. Other financial support from FCT (grant PTDC/ESC/71080/2006) is also gratefully acknowledged. Miguel Torres Preto gratefully acknowledges FCT for a Doctoral Scholarship (grant SFRH/BD/22648/2005). We are indebted to the Portuguese Ministry of Labor and Social Solidarity for allowing us access to the data used in this paper.

\footnotetext{
${ }^{1}$ Corresponding author: Phone: +351 218417 379. Fax: + 351218496 156. E-mail address: rui.baptista@ist.utl.pt (Rui Baptista).
} 


\section{Introduction}

A considerable amount of theoretical and empirical work in economics focuses on individual choices between wage employment and business ownership (or entrepreneurship). Seminal work by Lucas (1978) and Jovanovic (1982) provide the basis for a significant stream of literature linking entrepreneurial ability to firm size dynamics, and the evolution of markets. Another literature stream examines the role played by pecuniary and non-pecuniary rewards in the occupational choice between self-employment and wage employment (see, for instance, Rees and Shah, 1986; and Taylor, 1996). Work originating mostly in the management and organizational theory literatures increasingly focuses on the individual decision to exit entrepreneurship (Gimeno et al., 1997; McGrath, 1999) and on the characteristics of former business owners who re-enter entrepreneurship (see, for instance Westhead and Wright, 1998).

Conversely, only a few recent studies examine how well individuals who forsake business ownership and return to wage employment fare in the labor market. Research comparing earnings of former business owners who have become wage employees with those of others of similar age and educational background who did not experience self-employment over their careers provides mixed results and generally fails to account systematically both for the matching between worker and firm characteristics, and the specifics of career dynamics within firms.

The present study uses longitudinal matched employer-employee data that include detailed information about individuals' backgrounds, job assignments, and career progress within firms to examine the impact of business ownership experience on job assignments, careers and wages. An explanation for the empirical evidence obtained is provided based on the extant theoretical literature, paying attention in particular to the framework proposed by Gibbons and Waldman (2006) with regard to task-specific human capital. We largely follow the broad empirical strategy employed by Baker et al. (1994a; 1994b), asking three main questions that seek to account for the main features of the impact of business ownership experience on careers and wages:

i. Are former business owners more or less likely to be assigned to higher levels in the firms' hierarchies at the time of hiring than other workers of comparable characteristics?

ii. Do former business owners progress up the job ladder faster or slower than other workers of comparable characteristics?

iii. What is the overall return to business ownership experience in the labor market?

The following section provides the background for this study and surveys the empirical literature examining wage incomes and the labor market performance of former business owners. The third section describes the dataset used in the present study. Section four presents empirical evidence on the role played by business ownership experience in the internal economics of the firm with regard to careers, while section five focuses on wages. Section 6 provides some concluding remarks.

For the purpose of the present study, we use a broad definition of entrepreneur, which deliberately overlaps with that of business owner, not delving into a conceptual distinction between those terms. The same applies for the definition of entrepreneurship, which must be understood in a broad economic sense. The terms 'entrepreneur' and 'business owner', as well as 'entrepreneurship experience' and 'business ownership experience' will be used interchangeably in the present work as including those individuals who report themselves as business owners, regardless of whether they have full or partial ownership, and have started, acquired or inherited the business. 


\section{Background}

\subsection{Entrepreneurship and the Ability to Supervise and Coordinate}

While entrepreneurship's links with risk/uncertainty and innovation have lately taken somewhat of a spotlight, entrepreneurial activities have also been connected with supervision and coordination tasks at least since the work of Say (1803/1971). In A Treatise on Political Economy or the Production, Distribution and Consumption of Wealth, the entrepreneur plays a central coordinating role both in production and distribution. Also within the firm, he is the coordinator and moreover, the modern leader and manager. Say is the first author to emphasize this managerial role for the entrepreneur.

For Marshall (1890/1920), within the firm, the owner/entrepreneur bears all the responsibility and exercises all control. The entrepreneur directs production and he is both the manager and employer. Kaldor (1934) stresses that, in addition to uncertainty-bearing, the "entrepreneurial function" includes supervision and coordination. Supervision is necessary in the case of cooperative production in order to ensure that contracts already entered into should, in fact, be carried out. Coordination, on the other hand, is that part which determines what sort of contracts should be entered into.

More recently, Lazear (2005) proposes a theory of entrepreneurship based on the view that entrepreneurship "is the process of assembling necessary factors of production consisting of human, physical, and information resources and doing so in an efficient manner" (Lazear, 2005, p. 649). An entrepreneur must possess the ability to combine talents and manage those of others. Furthermore, he must combine those talents with physical capital and ideas to create a new product or to produce an existing one at a lower or competitive cost. Because the entrepreneur must bring together many different resources, he must have knowledge, at least at a basic level, of a large number of business areas.

Lazear's theory predicts that individuals with more balanced skill sets (i.e. generalists rather than specialists) are more likely to become entrepreneurs, and will enjoy higher entrepreneurial incomes. He tests the predictions of the theory using data on Stanford University alumni (Lazear, 2004; 2005) finding that those who have more varied work experience are more likely to be entrepreneurs; and students who study a more varied curriculum are more likely to become entrepreneurs. A further test of Lazear's theory is provided by Wagner (2003) based on a representative sample of the German working population. ${ }^{2}$ Wagner's findings give support to Lazear's theory, as the estimated probabilities of being self-employed are positively related with both the number of different kinds of professional training and the number of changes of professions.

In a recent paper, Åstebro and Thompson (2011) suggest an alternative view to that of Lazear. They predict that those with greater taste for variety are more likely to invest in generalist skills and become entrepreneurs, but entrepreneurs will actually see their incomes decrease with greater skill variety. Using data from a survey of entrepreneurs and individuals from the general population, they confirm that entrepreneurs typically have a more varied labor market experience. However, the more varied their experience, the lower their household income.

Regardless of the theory behind the motivation to become an entrepreneur, individuals with business ownership experience are more likely to have acquired the abilities necessary to organize a business, and lead, supervise, and coordinate others' efforts. Even if individuals are not endowed with the complete set of skills necessary to start and run a business, they can acquire those skills while doing it (Lazear, 2004). Both the views by Lazear (2005) and Astebro and Thompson (2011) imply that human capital investment patterns should differ between those who end up being entrepreneurs and those who end up working for others. It may be possible that the exercise of business ownership provides former entrepreneurs with experience in

\footnotetext{
${ }^{2}$ Lazear originally published his theory of entrepreneurship in an NBER Working Paper (\#9109, August 2002). Wagner's test is based on that version of Lazear's work.
} 
organizing, supervising and coordinating activities in firms. This experience could be valued by employing firms as a positive signal when hiring, promoting to the higher levels of their hierarchies, and establishing wages. Our paper aims to test these implications.

\subsection{Business Ownership Experience and Job Assignment, Wage, and Promotion Dynamics}

Comprehensive analyses of the internal organization of firms are found in works by Doeringer and Piore (1971); Rosenbaum (1984); and Baker et al. (1994a; 1994b). ${ }^{3}$ We are concerned with three main determinants that lead to specific worker-job matching - human capital, imperfect information, and the scale of operations of the firm - and how these factors affect the abilities held especially by those with business ownership experience - that of organizing, coordinating and supervising activities in firms.

Human capital theory (Becker, 1962; 1964/1975; Ben-Porath, 1967) states that individuals can acquire productivity-enhancing abilities through education and on-the-job training. The assignment of workers to jobs in the economy should then occur as a result of the knowledge firms and workers have of the output from each specific worker-job match. However, such knowledge is usually imperfect (Spence, 1975). Workers may then be sorted into jobs through mechanisms of screening and signaling (Stiglitz, 1975; Spence, 1973), or a matching process of workers to jobs (Jovanovic, 1979; 1984). Baker et al. (1994a) provide evidence that firms use the job assignments of workers as a signal of ability (see also Waldman, 1984; Bernhardt, 1995). It can then be argued that firms should seek those with organization and supervisory/coordination experience when filling up vacancies in managerial levels of the hierarchy which typically require these abilities. If business ownership is perceived as providing such abilities, then it is possible that entrepreneurial experience may be interpreted as a signal in the employment of supervisors/managers.

The assignment of workers to jobs is also influenced by the scale of operations of firms. More resources (i.e. capital and labor) are allocated to workers with greater supervisory/coordination abilities (Mayer, 1960; Williamson, 1967; Rosen, 1981; Spurr, 1987). Such workers will have a greater impact on the firm's output. The relationship between firm size and assignment of workers to jobs is also related to information asymmetries and compensation of workers within hierarchies, an argument originally put forward by Simon (1957). Calvo and Wellisz (1979) show that moral hazard occurs within firm hierarchies. Moral hazard provides a rationale for incentive mechanisms to avoid shirking that are particularly significant for workers in supervisory/coordination jobs (Harris and Holmstrom, 1982).

Under perfect information, or with efficient screening/signaling and incentive mechanisms, the pecuniary value of human capital should translate into greater earnings (Mincer, 1974). If entrepreneurial experience provides individuals with specific skills in supervisory/coordination tasks, such experience may allow them to have a significant impact on firm productivity as wage employees.

Gibbons and Waldman (1999) provide a general framework integrating job assignment, human-capital acquisition, and learning capturing several empirical findings concerning wage and promotion dynamics inside firms. In particular, their model provides a rationale for some important features of the internal economics of the firm (Baker et al., 1994a; 1994b):

i. Job assignments (i.e. hierarchical levels) are a stronger determinant of wage levels than human capital or any other observed characteristic of workers;

ii. There is a significant overlap between wages in adjacent hierarchical levels; and

iii. Wage increases are serially correlated, and promotions are associated with large wage increases, but wage increases at promotion are small relative to the difference between average wages across levels of the job ladder.

\footnotetext{
${ }^{3}$ Other examples of studies on the internal labor markets include Lazear and Oyer (2004) using multifirm data, and Dohmen et al. (2004) and Lin (2005) using single firm data. Waldman (2010) presents an extensive discussion survey of the related literature.
} 
In an extension to their model, Gibbons and Waldman (2006), show that the existence of task-specific human capital allows for the explanation of another characteristic of the internal economics of the firm: the existence of cohort effects. Studies by Beaudry and DiNardo (1991), and Baker et al. (1994b) show that a cohort's average wage upon entering the firm is an important determinant of that same cohort's average wage years later, independently of the cohorts' observable characteristics. The explanation for the cohort effect provided by Gibbons and Waldman $(2004 ; 2006)$ is that human capital accumulation is task-specific and its effect on productivity diminishes the further up a worker climbs in the job ladder. Some of a worker's acquired human capital goes unused when a worker is promoted and is assigned a new set of tasks. Hence, workers entering into lower levels in the job ladder accumulate human capital specific to the execution of tasks performed in those lower levels - being unlikely to acquire human capital specific to the supervisory/coordination activities required at higher levels. This means that their career progress will be slower than that of individuals who possess such human capital. ${ }^{4}$ It can then be suggested that, if some workers have acquired abilities specific to supervisory/coordination activities in the past, while being business owners, such workers have an advantage in progressing up the job ladder towards more managerial job levels.

\subsection{Business Ownership Experience and Wage Earnings}

Empirical work on the impact of business ownership experience on careers in firms is, to our knowledge, absent from the literature. Some recent work has examined the impact of such experience on individuals' wages, while other studies have compared earnings in selfemployment with those in paid employment. In general these studies argue that business ownership experience should exert a negative influence on earnings, as wage employees benefit from on-the-job training while former business owners do not (Williams, 2000).

In their path-breaking study, Evans and Leighton (1989) find no clear evidence that the return to experience in business ownership is different than the return to experience in wage work. When examining the possibility of a labor market 'stigma' for individuals with previous self-employment experience, Hamilton (2000) finds that a brief experience as a business owner yields a positive effect on subsequent wages as an employee, but that such effect wears away when long spells of entrepreneurial experience are considered.

Only recently, empirical analyses have paid attention primarily to the effects of entrepreneurial experience on individuals' earnings after they exit business ownership. Typically, empirical works on this subject find effects of business ownership experience on future employment earnings that are of small magnitude and weakly significant. Generally, even when positive, the effect of business ownership (or, in some cases, self-employment) experience on future wages is found to be smaller than the effect of past experience as a wage employee (Ferber and Waldfogel, 1998; Williams, 2000; 2004; Bruce and Schuetze, 2004; Hyytinen and Rouvinen, 2008; Kaiser and Malchow-Møller, 2011). However, with the exception of Kaiser and Malchow-Møller (2011), these studies do not provide evidence of where former business owners end up in the job assignment structure of firms.

In general, the empirical evidence concerning the wage returns to business ownership experience is mixed and unfinished. The studies do not address features of the internal economics of firms such as job assignments and promotions, thus providing an incomplete picture of the role played by business ownership experience on wage and career dynamics. The present study contributes to the literature by addressing these issues.

\footnotetext{
${ }^{4}$ As Waldman (2010) stresses, this approach can also explain the economy-wide cohort effects and industry-level cohort effects found in recent papers such as Oyer (2006), Oreopoulos et al. (2008), and Kahn (2010).
} 


\section{Data}

The present study uses the Quadros de Pessoal (QP) micro-data, a Portuguese longitudinal matched employer-employee dataset including extensive information on the mobility of workers and business owners for the period 1986-2003. ${ }^{5}$ QP is gathered annually by the Portuguese Ministry of Labor and includes data from all private firms (and establishments) with at least one wage-earner. The dataset does not cover public administration. The survey collects detailed information on each individual employee (regular wages, subsidies, hours worked, date of admission, age, gender, schooling, qualification level, part-time status, job assignment, and type of collective agreement, among others). It also collects basic information about the establishment and the firm, such as size, ownership, sales turnover, International Standard Industrial Classification (ISIC) codes, and location.

The present analysis uses information concerning the period 1995-2003. The employment and wage data refer to information provided by firms in the month of October of each year. The raw data used is organized in two datasets corresponding to the level of aggregation of the information: individual level and firm level. There are over 250,000 firms and two million workers in each annual survey who can be tracked over time through a unique identification number. Data on business owners and employees for each firm and establishment includes income (for employees), gender, age, occupation, tenure, educational attainment, and hierarchical levels. For both business owners and employees, records of wage employment and entrepreneurial experience can be collected, as well as information concerning labor market experiences following business ownership. The variable measuring experience (i.e. time) as wage employee is equal to age minus the sum of six, plus years of education, tenure, and years spent as a business owner.

The Portuguese labor market is one of the most regulated markets in Europe, yet this regulation coexists with high wage flexibility. The institutional framework is characterized by national minimum wage enforcement, widespread trade union influence and extension of collective bargaining contracts. Cardoso (2006) and Cardoso and Portugal (2005) show that this institutional framework imposes weak constraints on wage setting. Micro conditions at the firm level are major determinants of the wage setting and make up for the relatively homogenous wage growth in collective bargaining (Cardoso, 2006). Firms often deviate from contractual wage negotiated in the collective contracts (Cardoso and Portugal, 2005). The difference between the contractual wage and the actual wage paid by firms ranges from $30 \%$ to $40 \%$ of the contractual wage. Firms' wage-setting policy is largely determined by worker and firm attributes showing a high degree of freedom to adjust to market conditions experienced at the firm level.

\subsection{Sample}

Our initial sample comprises all young male individuals present in the data in 1995 who appear as employees in at least one year from 1986 to 2003, including those individuals who remain ever as employees and those who experience both wage employment and business ownership at different points in time. A panel was built to trace backwards the individuals' experiences in the labor market - between 1986 and 1995.

The period under scrutiny ranges from 1995 to 2003. This empirical study uses information on individuals who have entered the QP micro-data sometime between 1986 and 1995 in order to trace their backgrounds, building information on the initial stock of labor market experience. As an initial condition, it is guaranteed that this variable captures not only the number of years individuals are observed as employees or business owners in the dataset, but traces back the individuals' complete work history in their current firms.

\footnotetext{
${ }^{5}$ Recent studies using QP data include: Mata and Machado (1996), Blanchard and Portugal (2001), Mata and Portugal (2002), Cabral and Mata (2003), Varejão and Portugal (2007), and Geroski et al. (2010).
} 
We restrict the analysis males - who account for 61 percent of all individuals present in the dataset in 1995 - and who were aged between 16 and 25 years in 1986, corresponding to 40 percent of the original sample. By excluding individuals over 25 years old, the analysis focuses on young individuals who have finished their formal education and have already entered the labor market. Moreover, it mitigates the issue of initial conditions arising from comparing individuals with very dissimilar work experiences and ages. We cannot reconstruct the career of the individuals prior to 1986. For example, former jobs, past promotions or past experience as business owners are not available. We select only males for this study in order to avoid dealing with specificities concerning entrepreneurship and career differences by gender. In this way, we reduce the heterogeneity of the individuals under study.

\subsection{Former Business Owners and Wage Employees}

Part of the motivation of this study is based on the contention that former business owners own human capital that is distinguishable from that of wage employees. Table 1 presents the descriptive statistics for the complete sample (1995-2003), comparing former business owners with those individuals who were always wage employees. One particular issue that will be discussed in detail further on in this study is whether there is a wage 'penalty' affecting former business owners. At first sight, it seems clear that former business owners have higher earnings in comparison with individuals without any experience of owning a business. ${ }^{6}$

Table 1 here

Three binary variables capture the workers' education, defined as: i) individuals who have completed compulsory education, which in Portugal, over the period under analysis, corresponds to a nine-year school enrolment; ii) individuals who have completed secondary education, which corresponds to a twelve-year school enrolment; and iii) individuals who have completed tertiary education, which usually corresponds to a five-year university/college degree.

Generally, former business owners are better educated on average than individuals who were always on wage employment. Focusing exclusively on the higher level of education (university graduate), only a very small percentage of individuals have this degree (3.2 percent) and the proportion of former business owners with tertiary education is twice the same proportion for individuals who were always wage employees (6.4 percent vs. 3.2 percent). Finally, average experience in wage employment of former business owners is greater than for individuals who were never business owners, but former business owners are, on average, older than wage employees.

Firm size is measured using the natural logarithm of the number of employees in the firm. As can be seen in Table 1, the majority of former business owners find employment in smaller firms when compared with wage employees. Table 2 presents the distribution of firms and workers across firm size categories. Micro and small firms (less than 50 employees) represent 92.9 percent of all firms. It should be stressed that micro and small firms hire 71 percent of former business owners, compared with only 50.2 percent of wage employees, which is a sizable difference.

Table 2 here

\footnotetext{
${ }^{6}$ Hourly wage is calculated by dividing the sum of base wage with regular payments by the number of monthly paid hours, deflated using the Consumer Price Index. Overtime payments are not included.
} 


\section{Evidence on Job Assignments}

Two major objectives of this study are to determine: i) whether former business owners are assigned to higher levels in the firm's hierarchy when they are hired, in comparison with other workers of similar characteristics; and ii) whether former business owners progress up the job ladder faster than other workers of comparable characteristics. To do so, it is necessary to analyze the distribution of hierarchical levels within the firm structure. In particular, it is important to be aware of which tasks are demanded of workers within each specific level, as well as which skills are required. ${ }^{7}$

The information available in the data on employee's job assignments (i.e. hierarchies within firms) consists of eight levels, from level one - apprentices - to level eight, which includes the top managers of the firm, that is those involved with strategic planning and organization-level leadership (which may or may not coincide with the business owner). As we go up the job ladder, task complexity, skill requirements, and the responsibility level increase. Levels six to eight may be considered managerial. Abilities associated with planning, organizing, supervising and coordinating activities become ever more required. Levels six and seven correspond to managing roles that, while possibly not requiring the kind of strategic vision and leadership associated with top managers, probably entail a strong component of supervisory/coordinating and group-level leadership abilities. This basically fits the rationale of Mintzberg (1973) in the sense that upper level jobs are usually associated with supervising and managing larger groups, coordinating across business units, and strategic planning; while lower level jobs depend more on specialized functional knowledge and performing less complex tasks. Table 3 presents the information on wage employees' and former business owners' hierarchical levels, disaggregated by firm size classes.

\section{Table 3 here}

The distribution of hierarchical levels is different for former business owners than for wage employees. A striking feature of the data is that the allocation of ex-business owners to top hierarchical levels is exceptionally high when compared with that of workers who were always wage employees. In particular, nearly 15 percent of former business owners fall into the top manager level (level eight), even when former business owners who have remained with the same business after selling it are excluded from the data. ${ }^{8}$ Only three percent of individuals who were never business owners are allocated to that top level. Moreover, about 27 percent of exbusiness owners in the sample are concentrated in the top three hierarchical levels. These may be considered the 'managerial' levels, the ones where leadership, supervisory and coordinating tasks are likely to represent most of the requirements. Only ten percent of other employees are allocated to those levels. The same pattern of job assignment is present across firm size; however, the differences in the top levels between former business owners and wage employees are more obvious in micro and small firms. This pattern of job assignment suggests an explanation to why a greater percentage of former business owners are employed in smaller

\footnotetext{
${ }^{7}$ QP micro-data discriminates the hierarchy in the firm as seen in Table A1 in the Annex to the paper, which provides a description of the job levels and the corresponding tasks and skills required by each level. The hierarchical levels comprise three dimensions: the type of task and its complexity; the level of responsibility/authority; and the skills necessary to perform the corresponding job. The eight levels are defined by the Ministry of Labor questionnaire filled by each firm as displayed in Table A1, and all firms have to use these levels when answering the survey. The objective of the Ministry of Labor is to have a common and comparable hierarchical structure across firms and there is no direct or prior connection with any type of wage setting process such as, for example, a central wage bargaining with unions.

${ }^{8}$ All business owners in the sample under analysis have changed firms. We exclude all cases of business owners who sold their firm but stayed on as managers.
} 
firms: if they are searching for a job at the top of the hierarchy (hierarchies predominantly display a pyramid-like shape) then their distribution across firm size is closer to the size distribution of firms than to the distribution of all workers across firm size.

Table 4 here

In order to check whether a relationship between the hierarchical level and worker's tenure within the firm is identifiable, Table 4 displays the cross-share of tenure across hierarchical levels comparing the former business owners with those individuals who were always wage employees. It is possible to observe that, for the higher hierarchical levels - from highly-skilled professionals to top managers - the proportions at time of entry of former business owners are greater than those of workers who were always wage employees. As years of tenure increase, we observe the expected movement up the hierarchy for both types of workers, but former business owners are promoted more frequently than the workers who were never business owners. After five years, the share of former business owners who are top managers increases from 11 percent to 17 percent, while the share of workers who were never business owners goes from three percent to four percent.

The relationship between tenure and hierarchical level is independent of the size of the firm given that the results are very similar for the three size categories and follow the trends detected earlier on Table 4. Former business owners concentrate in a larger share on the top three hierarchical levels than wage employees and, consequently, the share of wage employees in the non-managerial (i.e. supervisory/coordination) levels is greater than the corresponding share of former business owners.

\subsection{Entry}

We begin by analyzing the job assignment at entry through the estimation of an ordered probit to determine whether the differences observed between the two types of workers - with and without business ownership experience - are reflected in the estimates on past experience, controlling for the remaining individual attributes and the characteristics of the firm. Table 5 presents the estimation results for job assignment at entry, disaggregating the effects of experience as business owner and experience as wage employee by considering one dummy variable for each year, ranging from one year to ten years or more. The dependent variable equals two if the worker is assigned to the top hierarchical level eight (the level where leadership skills/tasks dominate); equals one if the worker is assigned to hierarchical levels six or seven (the remaining managerial levels, where supervisory/coordination tasks dominate); and equals zero otherwise (levels one to five). All assignments occur at the moment of hiring (when tenure equals zero).

\section{Table 5 here}

Coefficients (measured as marginal effects) associated with former business ownership experience are always significant greater than those for experience as wage employee. For instance, a worker with two years of experience as a business owner has a probability of assignment to the top job level larger than 30 percent, while a worker with two years of experience as a wage employee only has a probability of assignment to the top job level of less than two percent. Moreover, a worker with two years of experience as a business owner has a probability of assignment to hierarchical levels six or seven of around 15 percent, whereas a worker with two years of experience as a wage employee only has a probability of assignment to these job levels of about two percent, again a sizable difference. These results suggest that 
business ownership experience is more valued at the moment of hiring than prior wage employment experience. Moreover, at entry, the marginal effects of past business ownership experience on the probability of being assigned to level eight (top manager) are greater than the marginal effects for the probability of being assigned to levels six or seven, which suggests that business ownership experience seems to be even more relevant for strategic leadership roles than for those roles with a stronger organizational supervisory/coordinating component. Note also that the effect on the probability of being assigned to the top manager level increases with years of past experience as business owner, meaning that there is a process of skill accumulation.

\subsection{Promotions}

In the previous section it became clear that former business owners are more likely to be assigned to higher levels in the firms' hierarchies at the time of hiring than wage employees of comparable characteristics. In this context, one plausible question arises: once entering a firm, do former business owners progress faster up the hierarchy? We can infer from Table 4 that former business owners spend less time at each hierarchical level than workers who were always wage employees, as the proportion of former business owners assigned to the top levels (especially to level eight) increases more than the same proportion for workers who remained always paid employees.

To further investigate this issue, Table 6 presents ordered probit estimates for the probability of being promoted from the highest non-managerial level (level five) to the supervisory/coordinating levels (six and seven) and to the top manager hierarchical level (eight), including instances in which workers were promoted first from a non-managerial level to a supervisory/coordinating level, and then from this level to that of top manager. The estimations provide evidence of the relative magnitude of the effects of different types of experience by disaggregating the effects of tenure, experience as business owner, as well as experience as wage employee using dummy variables that range from one year to ten or more years.

Estimation includes all workers assigned to the top non-managerial level (level five) at the time of hiring. Given that wage employees are clustered at the bottom of the hierarchy, we choose an entry hierarchical level close to the threshold level between non-managerial and managerial positions. In this way, the level upon firm entry does not confound the likelihood of promotion. The dependent variable equals two if the worker is promoted from the top nonmanagerial level (five) to the top managerial level (eight), regardless of this promotion happening directly or in two stages (first from a non-managerial level to a supervisory/coordinating level, and then from this level to that of top manager); equals one if the worker is promoted from the top non-managerial level to a supervisory/coordinating level (six and seven); and zero otherwise (the worker remains assigned to the non-managerial level five).

\section{Table 6 here}

The estimation results show that the probability of being promoted from the top nonmanagerial level to a managerial hierarchical level (six to eight) increases with tenure. The effect of business ownership experience on the probability of promotion to a managerial level is always higher than the corresponding effect for experience as a wage employee (which is not significant until the worker reaches six years of experience, and after that is always less than three percent), and increases with time spent in business ownership. Workers with superior amounts of experience as business owners have a higher probability of being promoted to the top managerial level (eight) when compared with the probability of promotion to the supervisory/coordinating levels six and seven. More specifically, for the first two years of business ownership experience, the partial effect of past business ownership experience is 
similar for promotion to levels six and seven and promotion to level eight; when business ownership experience is higher than two years, the effect on the promotion probability is greater for promotion to the top level (eight). Moreover, the change of the marginal effects as years of business owner experience increase is higher for the promotion to the top managerial level - it ranges from nine percent for one year of experience to 26 percent for ten years or more, whereas the change in the promotion probability to supervisory/coordinating levels ranges from 11 to 17 percent.

A possible explanation for these results is that former business owners may possess a kind of task-specific human capital (Gibbons and Waldman, 2004; 2006). In particular, entrepreneurial experience may allow individuals to accumulate greater experience in planning, organizing, supervising, coordinating, and leading activities. Firms may use business ownership experience as an outside signal about the workers' ability (Waldman, 1984; Bernhardt, 1995) to perform in higher hierarchical levels, and thus hire former business owners to higher job levels. The higher the job level a worker is assigned to, the more likely he is to acquire more supervisory/coordination ability. If this ability is a requirement for career progression, then former business owners, being more likely to have initially been assigned to a higher job level, should also progress faster up the job ladder. This effect is akin to the cohort effect highlighted by Gibbons and Waldman (2006).

\section{Evidence on Earnings}

We compare individual earnings using hourly wages (while in wage employment) over the period 1995-2003 as the variable of interest. ${ }^{9}$ We investigate whether experience as a business owner has a significant impact on the individuals' earnings while wage employees. Wage equations are defined for all the periods after the reference year, i.e. from 1995-2003, providing a total of over 2.4 million observations. The explanatory variables include years of experience as a business owner and as a wage employee. We use these two indicators to determine the value of the two types of human capital. Other explanatory variables include individual characteristics such as education and tenure. We exclude firm characteristics and job assignment from the estimation since our objective is capturing the wage effect of former business ownership in the labor market. Moreover, in the context of our estimation, such variables are endogenous.

\subsection{Empirical Specification}

We specify a panel data model of wage determination as

$$
\log \left(w_{i t}\right)=x_{i t} \beta+v_{i t}
$$

where $i$ indexes worker and $t$ indexes time period; $w_{i t}$ is the hourly wage received by worker $i$ in period $t ; x_{i t}$ is a vector of individual characteristics including education (three dummy variables), tenure (and its squared term), years of accumulated experience as a business owner (and its squared term), and years of accumulated experience as a wage employee (and its squared term); and $v_{i t}$ is the error term. This last unobserved part of the model can be divided into two components: an individual effect, $\alpha_{i}$ and an idiosyncratic error $u_{i t}$. These components define a composite error $v_{i t} \equiv \alpha_{i}+u_{i t}$.

\footnotetext{
${ }^{9}$ The dataset provides no information with regard to individuals' earnings while in business ownership. As an example, if one individual in the dataset has a brief experience as a wage employee and, before 1995, switches into business ownership and remains so thereafter, the model will drop this observation since there is no available information on this individual's earnings after 1995.
} 
The pooled ordinary least squares estimation (hereafter OLS) of equation (1) is consistent if there is no correlation between the regressors and $v_{i t}$, which implies assuming no correlation between the regressors and each component of the composite error. This assumption is unlikely to hold as, for example, education is probably correlated with individual unobserved heterogeneity $\alpha_{i}$. Nevertheless, the estimation of equation (1) by pooled OLS is reported to serve as a reference for comparing wage levels across individuals.

Assuming strict exogeneity of the regressors conditional on the unobserved effects,

$$
\mathrm{E}\left(u_{i t} \mid x_{i t}, \alpha_{i}\right)=0 \quad t=1, \ldots, T
$$

Equation (1) can be estimated by a fixed effects model as

$$
\log \left(w_{i t}\right)=x_{i t} \beta+\alpha_{i}+u_{i t}
$$

Our objective is to account for worker unobserved heterogeneity and obtain within estimators. We discuss below how the coefficients are identified and their interpretation.

\subsection{Rewards to Business Ownership Experience}

This sub-section introduces wage equations and begins by analyzing the moment of entry into the firm. Only workers with one year or less of tenure are included in the regressions presented in Column 1 of Table 7. The advantage of estimating wages at entry is that the results are not affected by tenure. Column 1 explains wages based on individual characteristics, such as education, experience as business owner, and experience as employee. ${ }^{10}$

Table 7 here

In general, the statistically significant variables associated with the accumulation of human capital have a positive effect on entry wages. Experience as wage employee shows decreasing returns, as the coefficients of the quadratic term is negative. The return starts at five percent and increases until 29 years of experience. Experience as a business owner shows a fairly constant return of less than one percent, given that the square term is not significant. Employers seem to value business ownership less than wage employment experience, thus penalizing entrepreneurial experience with a lower wage premium at the moment of hiring. ${ }^{11}$

In order to understand the effect of business ownership experience on wages, in this section we also present wage equations for the period 1995-2003 for all workers (without any restriction on tenure). The differences between former business owners and wage employees are a critical issue in the context of this study. It is therefore relevant to understand whether those individuals who had a first experience as business owners over the period 1995-2003 (about 3,000 observations) have some idiosyncratic characteristic which is not captured through human capital variables. If that is the case, we would be facing a selection issue. One way to deal with this question is through the introduction of a dummy variable discriminating those individuals who will become business owners when estimating wages during the period on wage employment prior to their first business ownership experience. If this dummy variable is statistically significant, it means that these individuals a priori are different from the remaining individuals, since they possess some unobserved characteristic which awards them greater earnings. Estimation results show that this variable is not significant, which means that future business owners are not initially different from other individuals. They become different only

\footnotetext{
${ }^{10}$ Squared terms are included to control for non-linear coefficients.

${ }^{11}$ The two returns only crossover after 35 years of experience.
} 
after a spell in business ownership, and are then recognized as so. ${ }^{12}$ This result implies that there is not a selection issue, at least for the period before acquiring business ownership experience. Furthermore, if there is no correlation between unobserved worker ability and future business ownership experience, it points to a legitimate causal interpretation of the results arising from the wage regressions estimated below.

The results of Column 2 of Table 7 present wage levels equations estimated by pooled OLS, controlling for tenure, tenure squared, education, and labor market experience variables, namely experience as business owner, experience as employee and the two corresponding squared terms. As with a typical wage regression, the variables associated with the accumulation of human capital have a positive, statistically significant effect on wages. Tenure and experience as employee show decreasing returns. The return to experience as wage employee starts at three percent and increases until 50 years of experience. The linear effect of experience as business owner is negative and the quadratic is positive, implying a starting negative return of one percent and becoming positive in the fifth year of experience. However, the effect of business owner experience is lower than the effect of wage employee experience. This relationship reverses at 17 years of experience, which is too far from the range of values used for the estimation, rendering a low precision for the estimates. Therefore, at first glance, evidence seems to confirm the idea that past experience as a business is associated with a wage penalty. ${ }^{13}$

\subsection{Rewards Accounting for Worker Fixed Effects}

The focus of this section is on fixed effects estimation, since the panel of individuals allows us to account for individual unobserved heterogeneity, as shown in equation (3) and presented on Column 3 of Table 7. We follow more than 450 thousand workers between 1995 and 2003, totaling 2.4 million observations. This gives us enough information to identify the within coefficients of the regression. In particular, when a worker moves from a firm to another, the movement contributes to the identification of the return to wage employee experience - the tenure in the former firm becomes experience. When a worker decides to create a business (in the period 1995-2003) and again moves to wage employment, he accumulates business ownership experience, allowing the identification of the respective coefficient. We expect that the worker fixed effect captures part of the non-randomness of these movements. However, some bias will remain - especially when the identification of the coefficients rests on a specific group of individuals - so we need to be cautious about the interpretation of the results.

The return to wage employment experience is positive but decreasing. It starts at 1.6 percent, increases 1.5 percentage points for the second year of experience and decays to zero as it approaches 18 years of experience. In contrast, the return to business ownership experience starts with a return close to zero in the first two years, but increases after that. In the first five years, the return is lower than the return to wage employment experience. In the sixth year of experience, the return of the ex-business owner experience is 11 percent and the return of the wage employment is nine percent. We estimate the same fixed effects regression separating the years of tenure and experience with a binary variable for each year and obtain similar results. ${ }^{14}$ As we mention above, some caution is required in interpreting these results. The average period of experience as business owner is 3.5 years with a standard deviation of 2.3 (Table 1). At this average, the return to business owner experience is three percent and the return to wage

\footnotetext{
12 This regression has also been conducted for each year of the time period. The dummy variables accounting for those individuals yet to become business owners were always non-significant. Results are available from the authors upon request.

${ }^{13}$ As the effect of experience is assumed to be quadratic in the previous estimations and the results can be driven by that assumption, a model was estimated using an indicator variable $(0,1)$ defined for each year of tenure and experience - both as business owner and wage worker. The results (not reported here but available from the authors upon request) are very close to the ones obtained using the quadratic specification.

${ }^{14}$ Results are available from the authors.
} 
employee experience is five percent (if we consider the same 3.5 years of wage employment experience), a clear advantage for those with employee experience. If we take into consideration the distribution of business ownership experience, only a small fraction of the ex-business owners will increase their stock of experience above the five years.

Overall, the value of business ownership experience in the market is lower than the value of wage employment experience. The results on job assignment (Section 4) show that business ownership experience increases the probability of entering the firm at (or be promoted to) a top hierarchical level. In micro and small firms, where former business owners predominantly find jobs (see Table 2), they can earn more than their co-workers by using their coordination and leadership skills. However when they are compared with similar workers in the market, irrespective of firm characteristics or job assignment, they earn less. The results on earnings also show that there is a specific group of former business owners who fare better in the labor market: those who have already accumulated sufficient leadership experience to enter the firm (or be promoted) to higher top hierarchical levels (in better paying firms). The identification of this kind of former business owners deserves more research, but is beyond the scope of this paper.

\section{Concluding Remarks}

This study examines the effect of business ownership experience on careers and earnings compared with wage employment experience. We look at the moment of entry and at career and wage progression within firms for workers who were business owners for at least one year and for workers who were never business owners. The results suggest that there are significant differences in career outlines between these two groups. Former business owners have a higher probability of entering a firm at a managerial job level than other workers and progress faster up the job ladder. With respect to earnings, the labor market seems to impose a penalty for business ownership experience. When we do not control for firm characteristics and job assignment, former business owners have a lower return for their experience as compared with the return to the experience as wage employee. So, even though former business owners hold a job assignment advantage, they are predominantly employed by smaller firms which render a smaller return to business ownership experience in the labor market.

Further work is necessary to address some unanswered questions. We find that for a specific group of workers, with longer time spent as business owners, the return to their experience was higher than the return to wage employment experience. It should be examined whether this is due to some selection bias (or an artifact of the sample) or if the length of business ownership experience allows for the accumulation of leadership skills rewarded by the labor market. Another issue regards success in business ownership. The present study does not distinguish between former business owners who closed their business due to lack of financial viability from those who sold or closed successful businesses. Performance in wage employment may differ between successful and unsuccessful former business owners. It should also be examined which industries hire former business owners and whether they are hired by firms in the same industries where they developed their entrepreneurial activity. Such work would shed light on the interaction between business ownership experience and industry-specific experience as sources of human capital acquisition. The information on different kinds of entrepreneurial history - length of the experience, the reasons to terminate it, the characteristics of the firms previously owned - offer paths to future research. 


\section{References}

Åstebro, T., Thompson, P. 2011. Entrepreneurs: Jacks of all trades or hobos? Research Policy 40(5), 637649.

Baker, G., Gibbs, M., Holmstrom, B. 1994a. The internal economics of the firm: evidence from personnel data. Quarterly Journal of Economics 109(4), 881-919.

Baker, G., Gibbs, M., Holmstrom, B. 1994b. The wage policy of a firm. Quarterly Journal of Economics 109(4), 921-955.

Beaudry, P., DiNardo, J., 1991. The effects of implicit contracts on the movement of wages over the business cycle: Evidence from microdata. Journal of Political Economy 99(4), $665-688$.

Becker, G.S., 1962. Investment in human capital: A theoretical analysis. Journal of Political Economy 70(5), 9-49.

Becker, G.S., 1975. Human capital. 2nd edition. New York, National Bureau of Economic Research (first edition 1964).

Ben-Porath, Y. 1967. The production of human capital and the life cycle of earnings. Journal of Political Economy 75(4), 352-365.

Bernhardt, D. 1995. Strategic promotion and compensation. Review of Economic Studies 62(2), 315-339.

Blanchard, O., Portugal, P. 2001. What hides behind an unemployment rate: Comparing Portuguese and U.S. labor markets. American Economic Review 91(1), 187-207.

Bruce, D., Schuetze, H.J. 2004. The labor market consequences of experience in selfemployment. Labour Economics 11(5), 575-598.

Cabral, L., Mata, J. 2003. On the evolution of the firm size distribution: Facts and theory. American Economic Review 93(4), 1075-1090.

Calvo, G.A., Wellisz, S. 1979. Hierarchy, ability, and income distribution. Journal of Political Economy 87(5), 991-1010.

Cardoso, A.R. 2006. Wage mobility: Do institutions make a difference? Labour Economics 13(3), 387-404.

Cardoso, A.R., Portugal, P. 2005. Contractual wages and the wage cushion under different bargaining settings. Journal of Labor Economics, 23(4): 875-902.

Doeringer, P.B., Piore, M.J. 1971. Internal labor markets and manpower analysis. Lexington, Heath Lexington Books.

Dohmen, T.J., Kriechel, B., Pfann, G.A. 2004. Monkey bars and ladders: The importance of lateral and vertical job mobility in internal labor market careers. Journal of Population Economics 17(2), 193-228.

Evans, D.S., Leighton, L.S. 1989. Some empirical aspects of entrepreneurship. American Economic Review 79(3), 519-535.

Ferber, M.A., Waldfogel, J. 1998. The long-term consequences of nontraditional employment. Monthly Labor Review 121(5), 3-12.

Geroski, P.A., Mata, J., Portugal, P. 2010. Founding conditions and the survival of new firms. Strategic Management Journal 31(5), 510-529.

Gibbons, R., Waldman, M. 1999. A theory of wage and promotion dynamics inside firms. Quarterly Journal of Economics 114(4), 1321-1358.

Gibbons, R., Waldman, M. 2004. Task-specific human capital. American Economic Review 94(2), 203-207.

Gibbons, R., Waldman, M. 2006. Enriching a theory of wage and promotion dynamics inside firms. Journal of Labor Economics 24(1), 59-107.

Gimeno, J., Folta, T.B., Cooper, A.C., Woo, C.Y. 1997. Survival of the fittest? Entrepreneurial human capital and the persistence of underperforming firms. Administrative Science Quarterly 42(4), 750-783.

Hamilton, B.H. 2000. Does entrepreneurship pay? An empirical analysis of the returns to selfemployment. Journal of Political Economy 18(3), 604-631.

Harris, M., Holmstrom, B. 1982. A theory of wage dynamics. Review of Economic Studies 49(3), 315-333. 
Hyytinen, A., Rouvinen, P. 2008. The labour market consequences of self-employment spells: European evidence. Labour Economics 15(2), 246-271.

Jovanovic, B. 1979. Job matching and the theory of turnover. Journal of Political Economy 87(5), 972-990.

Jovanovic, B. 1982. Selection and the evolution of industry. Econometrica 50(3), 649-670.

Jovanovic, B. 1984. Matching, turnover, and unemployment. Journal of Political Economy 92(1), 108-122.

Kahn, L.B. 2010. The long-term labor market consequences of graduating from college in a bad economy. Labour Economics 17(2), 303-316.

Kaiser, U., Malchow-Møller, N. 2011. Is self-employment really a bad experience? The effects of previous self-employment on subsequent wage employment wages. Journal of Business Venturing 26(5), 572-588.

Kaldor, N. 1934. The equilibrium of the firm. Economic Journal 44, 60-76.

Lazear, E.P. 2004. Balanced skills and entrepreneurship. American Economic Review 94(2), 208-211.

Lazear, E.P. 2005. Entrepreneurship. Journal of Labor Economics 23(4), 649-680.

Lazear, E.P., Oyer, P. 2004. Internal and external labor markets: A personnel economics approach. Labour Economics 11(5), 527-544.

Lin, M.-J. 2005. Opening the black box: The internal labor markets of company X. Industrial Relations 44(4), 659-706.

Lucas, R.E. 1978. On the size distribution of business firms. Bell Journal of Economics 9(2), 508-523.

Marshall, A. 1920. Principles of Economics. London, Macmillan and Co. (first edition 1890).

Mata, J., Machado, J.A.F. 1996. Firm Start-Up Size: A Conditional quantile approach. European Economic Review 40(6), 1305-1323.

Mata, J., Portugal, P. 2002. The survival of new domestic and foreign-owned firms. Strategic Management Journal 23(4), 323-343.

Mayer, T. 1960. The distribution of ability and earnings. Review of Economics and Statistics 2(2), 189-195.

McGrath, R.G. 1999. Falling forward: Real options reasoning and entrepreneurial failure. The Academy of Management Review 24(1), 13-30.

Mincer, J. 1974. Schooling, experience, and earnings. New York, Columbia University Press.

Mintzberg, H. 1973. The nature of managerial work. New York, Harper \& Row.

Oreopoulos, P., Wachter, T. von, Heisz, A. 2008. The short- and long-term career effects of graduating in a recession: Hysteresis and heterogeneity in the market for college graduates. IZA Discussion Paper No. 3578.

Oyer, Paul. 2006. Initial labor market conditions and long-term outcomes for economists. Journal of Economic Perspectives 20(3), 143-160.

Rees, H., Shah, A. 1986. An empirical analysis of self-employment in the U.K. Journal of Applied Econometrics 1(1), 101-108.

Rosen, S. 1981. The economics of superstars. American Economic Review 71(5), 845-858.

Rosenbaum, J.E. 1984. Career mobility in a corporate hierarchy. London, Academic Press.

Say, J.-B. 1971. A treatise on political economy or the production, distribution and consumption of wealth. New York, A.M. Kelley Publishers (first edition 1803).

Simon, H.A. 1957. The compensation of executives. Sociometry 20, 32-35.

Spence, A.M. 1973. Job market signaling. Quarterly Journal of Economics 87(3), 355-374.

Spence, A.M. 1975. The economics of internal organization: An introduction, Bell Journal of Economics 6(1), 163-172.

Spurr, S.J. 1987. How the market solves an assignment problem: The matching of lawyers with legal claims. Journal of Labor Economics 5(4), 502-532.

Stiglitz, J. 1975. The theory of screening education and the distribution of income. American Economic Review 65(3), 283-300.

Taylor, M.P. 1996. Earnings, independence or unemployment: Why become self-employed? Oxford Bulletin of Economics and Statistics 58(2), 253-266. 
Varejão, J., Portugal, P. 2007. Employment dynamics and the structure of labor adjustment costs. Journal of Labor Economics 25(1), 137-165.

Wagner, J. 2003. Testing Lazear's jack-of-all-trades view of entrepreneurship with German microdata. Applied Economics Letters 10(11), 687-689.

Waldman, M. 1984. Job assignments, signaling, and efficiency. Rand Journal of Economics $15(2), 255-267$.

Waldman, M. 2010. Theory and evidence in internal labor markets. In: Gibbons, R., Roberts, J. (Eds.), Handbook of Organizational Economics, Princeton, Princeton University Press (forthcoming 2010).

Westhead, P., Wright, M. 1998. Novice, portfolio and serial founders: Are they different? Journal of Business Venturing 13(3), 173-204.

Williams, D.R. 2000. Consequences of self-employment for women and men in the United States. Labour Economics 7(5), 665-687.

Williams, D.R. 2004. Youth self employment: Its nature and consequences. Small Business Economics 23(4), 323-336.

Williamson, O.E. 1967. Hierarchical control and optimum firm size. Journal of Political Economy 75(2), 123-138. 


\section{Annex}

Table Al Job (hierarchical) levels

\begin{tabular}{|c|c|c|}
\hline Level & Tasks & Skills \\
\hline 8 - Top managers & $\begin{array}{l}\text { Definition of the firm general } \\
\text { policy or consulting on the } \\
\text { organization of the firm. } \\
\text { Strategic planning. } \\
\text { Creation or adaptation of } \\
\text { technical, scientific and } \\
\text { administrative methods or } \\
\text { processes. }\end{array}$ & $\begin{array}{l}\text { Knowledge of management and } \\
\text { coordination of firm's } \\
\text { fundamental activities. } \\
\text { Knowledge of management and } \\
\text { coordination of the fundamental } \\
\text { activities in the field to which the } \\
\text { individual is assigned and that } \\
\text { requires the study and research } \\
\text { of high responsibility and } \\
\text { technical level problems. }\end{array}$ \\
\hline 7 - Intermediary managers & $\begin{array}{l}\text { Organization and adaptation of } \\
\text { the guidelines established by the } \\
\text { superiors and directly linked with } \\
\text { the executive work. }\end{array}$ & $\begin{array}{l}\text { Technical and professional } \\
\text { qualifications directed to } \\
\text { executive, research, and } \\
\text { management work. }\end{array}$ \\
\hline $\begin{array}{l}6 \text { - Supervisors, team leaders, } \\
\text { foremen }\end{array}$ & $\begin{array}{l}\text { Orientation and supervision of } \\
\text { teams, as directed by superiors, } \\
\text { but requiring the knowledge of } \\
\text { tasks. }\end{array}$ & $\begin{array}{l}\text { Complete professional } \\
\text { qualification with a } \\
\text { specialization. }\end{array}$ \\
\hline $\begin{array}{l}5 \text { - Higher-qualified } \\
\text { professionals }\end{array}$ & $\begin{array}{l}\text { Tasks requiring a high technical } \\
\text { value and defined in general } \\
\text { terms by superiors. }\end{array}$ & $\begin{array}{l}\text { Complete professional } \\
\text { qualification with a specialization } \\
\text { adding to theoretical and applied } \\
\text { knowledge. }\end{array}$ \\
\hline 4 - Qualified professionals & $\begin{array}{l}\text { Complex or delicate tasks, } \\
\text { usually not repetitive and } \\
\text { defined by superiors. }\end{array}$ & $\begin{array}{l}\text { Complete professional } \\
\text { qualification implying theoretical } \\
\text { and applied knowledge. }\end{array}$ \\
\hline 3 - Semi-qualified professionals & $\begin{array}{l}\text { Well defined tasks, mainly } \\
\text { manual or mechanical with low } \\
\text { complexity, usually routine and } \\
\text { sometimes repetitive. }\end{array}$ & $\begin{array}{l}\text { Professional qualification in a } \\
\text { limited field or practical and } \\
\text { elementary professional } \\
\text { knowledge. }\end{array}$ \\
\hline 2 - Non-qualified professionals & $\begin{array}{l}\text { Simple tasks, diverse and } \\
\text { usually not specified, totally } \\
\text { determined. }\end{array}$ & $\begin{array}{l}\text { Practical knowledge and easily } \\
\text { acquired in a short time. }\end{array}$ \\
\hline $\begin{array}{l}1 \text { - Apprentices, interns, } \\
\text { trainees }\end{array}$ & Training for a specific task & $\begin{array}{l}\text { Identical, but without practice, to } \\
\text { the professional of the } \\
\text { qualification level they will be } \\
\text { assigned }\end{array}$ \\
\hline
\end{tabular}

Notes: Hierarchical levels as defined by law - Decreto Lei $121 / 78$ of July 2 . 
Table 1 Descriptive statistics, 1995-2003

\begin{tabular}{llll}
\hline Variables & All workers & Former business owners & Wage employees \\
\hline Wage per hour (logarithm) & 1.389 & 1.439 & 1.388 \\
Age & {$[0.546]$} & {$[0.606]$} & {$[0.545]$} \\
& 30.176 & 33.073 & 30.138 \\
Tenure & {$[5.336]$} & {$[4.459]$} & {$[5.336]$} \\
9-years education & 7.021 & 5.913 & 7.035 \\
& {$[5.108]$} & {$[5.750]$} & {$[5.111]$} \\
Secondary education & 0.166 & 0.187 & 0.166 \\
& {$[0.372]$} & {$[0.390]$} & {$[0.372]$} \\
College education & 0.167 & 0.191 & 0.166 \\
& {$[0.373]$} & {$[0.393]$} & {$[0.372]$} \\
Experience as business owner & 0.032 & 0.064 & 0.032 \\
& {$[0.177]$} & {$[0.244]$} & {$[0.176]$} \\
Experience as employee & {$[0.380]$} & 3.495 & -- \\
& 12.134 & {$[2.269]$} & -- \\
Firm size (logarithm) & {$[6.318]$} & 13.074 & 12.122 \\
& 4.205 & {$[6.488]$} & {$[6.315]$} \\
$\mathrm{N}$ & {$[2.226]$} & 3.164 & 4.218 \\
\hline
\end{tabular}

Notes: Standard deviation between brackets underneath the mean. Hourly wage is calculated by dividing the sum of base wage with regular payments by the number of monthly paid hours, deflated using the Consumer Price Index. Tenure, experience as business owner, and potential experience as employee are measured in years. 9-years of education, secondary education, and college education are defined as dummy variables. 
Table 2 Firms and workers, 1995-2003

\begin{tabular}{lllllllll}
\hline Firm size class & \multirow{2}{*}{ Firms } & \multicolumn{3}{c}{ All workers } & \multicolumn{3}{c}{ Former business } & Wwners \\
\hline Micro \& small & 157,203 & $92.9 \%$ & $1,217,933$ & $50.4 \%$ & 21,947 & $71.0 \%$ & $1,195,986$ & $50.2 \%$ \\
firms & 11,434 & $6.8 \%$ & 743,298 & $30.8 \%$ & 6,651 & $21.5 \%$ & 736,647 & $30.9 \%$ \\
Medium firms & 552 & $0.3 \%$ & 453,392 & $18.8 \%$ & 2,306 & $7.5 \%$ & 451,086 & $18.9 \%$ \\
Large firms & 169,189 & $100 \%$ & $2,414,623$ & $100 \%$ & 30,904 & $100 \%$ & $2,383,719$ & $100 \%$ \\
Total & & & & &
\end{tabular}

Notes: Firm size is divided into three classes: micro and small firms, medium firms, and large firms. Micro and small firms are those firms with less than 50 employees. Medium firms are those firms between 50 and 499 employees. Large firms are those firms with more than or equal to 500 employees. 
Table 3 Hierarchical levels and firm size, 1995-2003

\begin{tabular}{llccc}
\hline Hierarchical level & \multicolumn{4}{l}{ Firm size (number of employees) } \\
\cline { 2 - 5 } & All & $<50$ & {$[50-500[$} & $\geq 500$ \\
\hline Former business owners & & & & 0.02 \\
1: apprentices, interns, trainees & 0.02 & 0.03 & 0.02 & 0.15 \\
2: non-skilled professionals & 0.06 & 0.05 & 0.07 & 0.10 \\
3: semi-skilled professionals & 0.08 & 0.08 & 0.10 & 0.43 \\
4: skilled professionals & 0.50 & 0.52 & 0.44 & 0.08 \\
5: higher-skilled professionals & 0.07 & 0.06 & 0.08 & 0.07 \\
6: supervisors and team leaders & 0.06 & 0.05 & 0.07 & 0.06 \\
7: intermediary managers & 0.06 & 0.06 & 0.06 & 0.10 \\
8: top managers & 0.15 & 0.15 & 0.16 & 0.01 \\
Wage employees & & & & 0.10 \\
1: apprentices, interns, trainees & 0.06 & 0.09 & 0.04 & 0.15 \\
2: non-skilled professionals & 0.09 & 0.09 & 0.09 & 0.47 \\
3: semi-skilled professionals & 0.14 & 0.11 & 0.17 & 0.11 \\
4: skilled professionals & 0.54 & 0.59 & 0.50 & 0.06 \\
5: higher-skilled professionals & 0.07 & 0.05 & 0.06 & 0.05 \\
6: supervisors and team leaders & 0.04 & 0.03 & 0.06 & 0.05 \\
7: intermediary managers & 0.03 & 0.02 & 0.04 & 0.04 \\
8: top managers & 0.03 & 0.02 & &
\end{tabular}

Notes: Each column presents the distribution of workers across hierarchical levels for former business owners and the remaining employees (the 'wage employees') calculated at different firm sizes. 
Table 4 Hierarchical level and tenure, 1995-2003

\begin{tabular}{lllllll}
\hline Hierarchical level & \multicolumn{7}{c}{ Tenure } \\
\cline { 2 - 7 } & 0 & 1 & 2 & 3 & 4 & 5 \\
\hline Former business owners & & & & & 0.03 \\
1: apprentices, interns and trainees & 0.04 & 0.03 & 0.03 & 0.02 & 0.02 & 0.03 \\
2: non-skilled professionals & 0.09 & 0.07 & 0.05 & 0.05 & 0.05 & 0.04 \\
3: semi-skilled professionals & 0.08 & 0.09 & 0.08 & 0.08 & 0.07 & 0.08 \\
4: skilled professionals & 0.51 & 0.52 & 0.50 & 0.50 & 0.49 & 0.48 \\
5: higher-skilled professionals & 0.06 & 0.07 & 0.08 & 0.07 & 0.06 & 0.07 \\
6: supervisors and team leaders & 0.05 & 0.06 & 0.06 & 0.06 & 0.06 & 0.06 \\
7: intermediary managers & 0.05 & 0.05 & 0.06 & 0.07 & 0.08 & 0.08 \\
8: top managers & 0.11 & 0.12 & 0.14 & 0.15 & 0.16 & 0.17 \\
\hline Wage employees & & & & & & 0.06 \\
\hline 1: apprentices, interns and trainees & 0.10 & 0.11 & 0.10 & 0.09 & 0.07 & 0.06 \\
2: non-skilled professionals & 0.16 & 0.13 & 0.11 & 0.10 & 0.09 & 0.08 \\
3: semi-skilled professionals & 0.12 & 0.12 & 0.13 & 0.14 & 0.14 & 0.15 \\
4: skilled professionals & 0.50 & 0.50 & 0.51 & 0.52 & 0.53 & 0.54 \\
5: higher-skilled professionals & 0.04 & 0.05 & 0.05 & 0.06 & 0.06 & 0.06 \\
6: supervisors and team leaders & 0.02 & 0.03 & 0.03 & 0.03 & 0.03 & 0.04 \\
7: intermediary managers & 0.02 & 0.03 & 0.03 & 0.03 & 0.03 & 0.03 \\
8: top managers & 0.03 & 0.03 & 0.04 & 0.04 & 0.04 & 0.04 \\
\hline
\end{tabular}

Notes: Each column presents the distribution of workers across hierarchical levels for former business owners and the remaining employees (the 'wage employees') calculated at tenure between zero years (the employee's entry year) and five years. 
Table 5 Ordered probit for job assignment at entry (marginal effects)

\begin{tabular}{|c|c|c|c|c|c|c|c|c|c|c|}
\hline Variables (dummies) & 1 year & 2 years & 3 years & 4 years & 5 years & 6 years & 7 years & 8 years & 9 years & $\geq 10$ years \\
\hline \multicolumn{11}{|c|}{ Worker is assigned to top hierarchical level (leadership level) } \\
\hline BO Experience & $\begin{array}{l}0.6282^{\star \star \star} \\
{[0.0062]}\end{array}$ & $\begin{array}{l}0.3284^{\star \star \star} \\
{[0.0142]}\end{array}$ & $\begin{array}{l}0.3624^{\star \star \star} \\
{[0.0164]}\end{array}$ & $\begin{array}{l}0.4321^{\star \star \star} \\
{[0.0201]}\end{array}$ & $\begin{array}{l}0.5085^{\star \star \star} \\
{[0.0238]}\end{array}$ & $\begin{array}{l}0.5057^{\star \star *} \\
{[0.0260]}\end{array}$ & $\begin{array}{l}0.5645^{\star \star *} \\
{[0.0307]}\end{array}$ & $\begin{array}{l}0.5830^{\star \star \star *} \\
{[0.0330]}\end{array}$ & $\begin{array}{l}0.6828^{\star \star \star} \\
{[0.0358]}\end{array}$ & $\begin{array}{l}0.7633^{\star \star \star} \\
{[0.0163]}\end{array}$ \\
\hline Employee experience & $\begin{array}{l}0.0059 \\
{[0.0074]}\end{array}$ & $\begin{array}{l}0.0125 \\
{[0.0082]}\end{array}$ & $\begin{array}{l}0.0165^{\star} \\
{[0.0085]}\end{array}$ & $\begin{array}{l}0.0285^{\star * *} \\
{[0.0103]}\end{array}$ & $\begin{array}{l}0.0370^{* * *} \\
{[0.0115]}\end{array}$ & $\begin{array}{l}0.0466^{* * *} \\
{[0.0127]}\end{array}$ & $\begin{array}{l}0.0588^{\star * *} \\
{[0.0141]}\end{array}$ & $\begin{array}{l}0.0625^{\star * *} \\
{[0.0145]}\end{array}$ & $\begin{array}{l}0.0749^{\star * \star} \\
{[0.0159]}\end{array}$ & $\begin{array}{l}0.0377^{\star * \star} \\
{[0.0022]}\end{array}$ \\
\hline \multicolumn{11}{|c|}{ Worker is assigned to hierarchical levels six or seven (supervision levels) } \\
\hline BO Experience & $\begin{array}{l}0.1246^{\star \star \star} \\
{[0.0018]}\end{array}$ & $\begin{array}{l}0.1518^{* * *} \\
{[0.0016]}\end{array}$ & $\begin{array}{l}0.1531^{* \star *} \\
{[0.0013]}\end{array}$ & $\begin{array}{l}0.1513^{* \star *} \\
{[0.0019]}\end{array}$ & $\begin{array}{l}0.1428^{* \star *} \\
{[0.0038]}\end{array}$ & $\begin{array}{l}0.1431^{\star * *} \\
{[0.0041]}\end{array}$ & $\begin{array}{l}0.1324^{\star * *} \\
{[0.0066]}\end{array}$ & $\begin{array}{l}0.1283^{\star \star *} \\
{[0.0077]}\end{array}$ & $\begin{array}{l}0.1004^{\star \star \star} \\
{[0.0118]}\end{array}$ & $\begin{array}{l}0.0718^{\star \star \star} \\
{[0.0067]}\end{array}$ \\
\hline Employee experience & $\begin{array}{l}0.0079 \\
{[0.0094]}\end{array}$ & $\begin{array}{l}0.0160^{*} \\
{[0.0096]}\end{array}$ & $\begin{array}{l}0.0206^{\star *} \\
{[0.0096]}\end{array}$ & $\begin{array}{l}0.0333^{\star * *} \\
{[0.0103]}\end{array}$ & $\begin{array}{l}0.0415^{\star * *} \\
{[0.0107]}\end{array}$ & $\begin{array}{l}0.0502^{* * *} \\
{[0.0109]}\end{array}$ & $\begin{array}{l}0.0604^{\star * *} \\
{[0.0111]}\end{array}$ & $\begin{array}{l}0.0633^{\star * *} \\
{[0.0112]}\end{array}$ & $\begin{array}{l}0.0726^{\star \star \star} \\
{[0.0112]}\end{array}$ & $\begin{array}{l}0.0586^{\star \star \star} \\
{[0.0033]}\end{array}$ \\
\hline Observations & 314,356 & & & & & & & & & \\
\hline Wald X-squared & 48345.96 & & & & & & & & & \\
\hline Pseudo R-squared & 0.332 & & & & & & & & & \\
\hline
\end{tabular}

Notes: Dependent variable equals two if the worker is assigned to top hierarchical level eight (leadership level), equals one if the worker is assigned to hierarchical levels six or seven (supervision levels), and zero otherwise (levels one to five), at the moment of hiring (tenure $=0$ ). Experience as business owner and experience as employee are defined as dummy variables ranging from one year to ten or more years. Estimations also include 9 -years of education, secondary education, college education, firm size, industry and region dummies. Standard errors are in brackets. ${ }^{\star}$ Significant at $10 \%$; ${ }^{* \star}$ significant at $5 \%$; ${ }^{* \star \star}$ significant at $1 \%$. 
Table 6 Ordered probit for promotion (marginal effects)

\begin{tabular}{|c|c|c|c|c|c|c|c|c|c|c|}
\hline Variables (dummies) & 1 year & 2 years & 3 years & 4 years & 5 years & 6 years & 7 years & 8 years & 9 years & $\geq 10$ years \\
\hline \multicolumn{11}{|c|}{ Worker is promoted to top hierarchical level (leadership level) } \\
\hline Tenure & $\begin{array}{l}0.2102^{\star \star \star} \\
{[0.0287]}\end{array}$ & $\begin{array}{l}0.3109^{\star \star \star} \\
{[0.0339]}\end{array}$ & $\begin{array}{l}0.3404^{\star \star \star} \\
{[0.0349]}\end{array}$ & $\begin{array}{l}0.3746^{* * *} \\
{[0.0357]}\end{array}$ & $\begin{array}{l}0.3800^{* * *} \\
{[0.0357]}\end{array}$ & $\begin{array}{l}0.3987^{* * *} \\
{[0.0363]}\end{array}$ & $\begin{array}{l}0.3856^{\star * *} \\
{[0.0360]}\end{array}$ & $\begin{array}{l}0.3852^{\star * *} \\
{[0.0359]}\end{array}$ & $\begin{array}{l}0.3980^{\star * \star} \\
{[0.0365]}\end{array}$ & $\begin{array}{l}0.2428^{* * *} \\
{[0.0209]}\end{array}$ \\
\hline BO Experience & $\begin{array}{l}0.0946^{* * *} \\
{[0.0103]}\end{array}$ & $\begin{array}{l}0.1373^{\star * *} \\
{[0.0176]}\end{array}$ & $\begin{array}{l}0.1902^{* * *} \\
{[0.0272]}\end{array}$ & $\begin{array}{l}0.1702^{* * *} \\
{[0.0240]}\end{array}$ & $\begin{array}{l}0.2797^{* * *} \\
{[0.0353]}\end{array}$ & $\begin{array}{l}0.2211^{* * *} \\
{[0.0373]}\end{array}$ & $\begin{array}{l}0.2556^{* * *} \\
{[0.0487]}\end{array}$ & $\begin{array}{l}0.3323^{* * *} \\
{[0.0537]}\end{array}$ & $\begin{array}{l}0.2640^{* * *} \\
{[0.0520]}\end{array}$ & $\begin{array}{l}0.2555^{\star * *} \\
{[0.0394]}\end{array}$ \\
\hline Employee experience & $\begin{array}{l}-0.0009 \\
{[0.0028]}\end{array}$ & $\begin{array}{l}0.0036 \\
{[0.0031]}\end{array}$ & $\begin{array}{l}0.002 \\
{[0.0028]}\end{array}$ & $\begin{array}{l}0.0024 \\
{[0.0028]}\end{array}$ & $\begin{array}{l}0.0027 \\
{[0.0028]}\end{array}$ & $\begin{array}{l}0.0012 \\
{[0.0027]}\end{array}$ & $\begin{array}{l}0.0067^{\star *} \\
{[0.0031]}\end{array}$ & $\begin{array}{l}0.0048 \\
{[0.0031]}\end{array}$ & $\begin{array}{l}0.0073^{\star *} \\
{[0.0033]}\end{array}$ & $\begin{array}{l}0.0117^{\star * *} \\
{[0.0026]}\end{array}$ \\
\hline \multicolumn{11}{|c|}{ Worker is promoted to hierarchical levels six or seven (supervision levels) } \\
\hline Tenure & $\begin{array}{l}0.1700^{* * *} \\
{[0.0101]}\end{array}$ & $\begin{array}{l}0.1910^{\star \star \star} \\
{[0.0048]}\end{array}$ & $\begin{array}{l}0.1935^{\star * *} \\
{[0.0036]}\end{array}$ & $\begin{array}{l}0.1945^{\star \star *} \\
{[0.0028]}\end{array}$ & $\begin{array}{l}0.1951^{* * *} \\
{[0.0028]}\end{array}$ & $\begin{array}{l}0.1939^{\star * \star} \\
{[0.0030]}\end{array}$ & $\begin{array}{l}0.1947^{\star \star \star} \\
{[0.0028]}\end{array}$ & $\begin{array}{l}0.1950^{\star * *} \\
{[0.0028]}\end{array}$ & $\begin{array}{l}0.1936^{\star * \star} \\
{[0.0030]}\end{array}$ & $\begin{array}{l}0.2108^{\star \star *} \\
{[0.0075]}\end{array}$ \\
\hline BO Experience & $\begin{array}{l}0.1074^{\star \star \star} \\
{[0.0075]}\end{array}$ & $\begin{array}{l}0.1338^{\star * *} \\
{[0.0094]}\end{array}$ & $\begin{array}{l}0.1569^{\star * *} \\
{[0.0098}\end{array}$ & $\begin{array}{l}0.1491^{* * *} \\
{[0.0100]}\end{array}$ & $\begin{array}{l}0.1782^{* * *} \\
{[0.0054]}\end{array}$ & $\begin{array}{l}0.1663^{\star * *} \\
{[0.0102]}\end{array}$ & $\begin{array}{l}0.1742^{\star * *} \\
{[0.0095]}\end{array}$ & $\begin{array}{l}0.1826^{\star * *} \\
{[0.0034]}\end{array}$ & $\begin{array}{l}0.1756^{\star * *} \\
{[0.0092]}\end{array}$ & $\begin{array}{l}0.1742^{\star * *} \\
{[0.0078]}\end{array}$ \\
\hline Employee experience & $\begin{array}{l}-0.0016 \\
{[0.0053]}\end{array}$ & $\begin{array}{l}0.0065 \\
{[0.0054]}\end{array}$ & $\begin{array}{l}0.0036 \\
{[0.0051]}\end{array}$ & $\begin{array}{l}0.0044 \\
{[0.0050]}\end{array}$ & $\begin{array}{l}0.0049 \\
{[0.0050]}\end{array}$ & $\begin{array}{l}0.0022 \\
{[0.0049]}\end{array}$ & $\begin{array}{l}0.0118^{\star *} \\
{[0.0053]}\end{array}$ & $\begin{array}{l}0.0086 \\
{[0.0053]}\end{array}$ & $\begin{array}{l}0.0129^{\star \star} \\
{[0.0056]}\end{array}$ & $\begin{array}{l}0.0215^{\star * *} \\
{[0.0046]}\end{array}$ \\
\hline Observations & 156,412 & & & & & & & & & \\
\hline Wald $X$-squared & 4947.88 & & & & & & & & & \\
\hline Pseudo R-squared & 0.096 & & & & & & & & & \\
\hline
\end{tabular}

Notes: Dependent variable equals two if the individual is promoted from a non-managerial level (level five) to the top manager level (level eight), regardless of this promotion happening directly or first from a level five to a supervisory/coordinating level, and then from this level to that of top manager; equals one if the worker is promoted from a nonmanagerial level (level five) to a supervisory/coordinating level (level six and seven); and zero if the worker remains assigned to the non-managerial level (level five). Tenure, experience as business owner and experience as employee are defined as dummy variables ranging from one year to ten or more years. Estimations also include 9-years of education, secondary education, college education, firm size, industry and region dummies. Standard errors are in brackets. ${ }^{*}$ Significant at $10 \%$; ${ }^{\star *}$ significant at $5 \%$; ${ }^{\star \star \star}$ significant at $1 \%$. 
Table 7 Wage equations

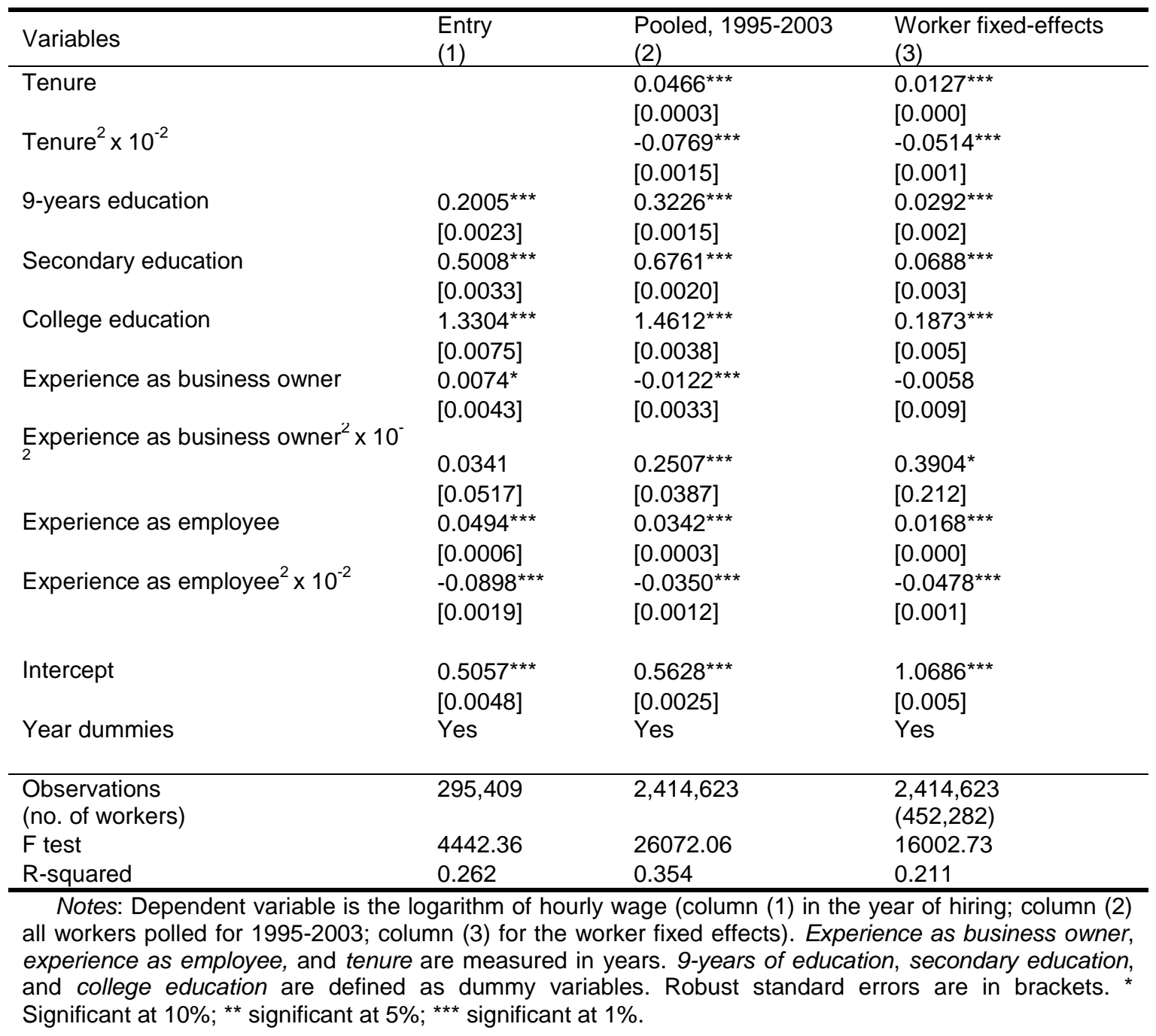

